\title{
CORRELATION OF BODY MASS INDEX AND LUNG VOLUME IN 3-7 YEAR-OLD CHILDREN IN RIIGA PRE-SCHOOL EDUCATIONAL INSTITUTIONS
}

\author{
Liene Martinsone-Bērzkalne" ${ }^{\#}$, Silvija Umbraško, Ilva Duḷevska, Liāna Pḷavina, \\ Viktorija Cīrule, and Anita Oginska
}

Institute of Anatomy and Anthropology, Rīga Stradiṇš University, 9. Kronvalda Blvd., Rīga, LV-1010, LATVIA

\# Corresponding author, Liene.Martinsone-Berzkalne@rsu.Iv

Communicated by Māra Pilmane

\begin{abstract}
The number of people with excess weight increases every year. Overweight and obesity in childhood can cause several chronic diseases in adulthood. Children with excess body mass develop more morphological and functional changes, including pulmonary functions. One of the common methods to assess lung function is spirometry. This method is a challenge in assessing lung function for pre-school age children. The aim of this study was to evaluate the correlation between lung vital capacity and body mass index for the pre-school children aged 3-7 years in Riga. In total 995 pre-school children were included in the study. An informative consent and questionnaire about the development of each individual child was filled in by parents. Several measurements were performed, including height, body mass, and lung vital capacity. This is the first study in Latvia where several morphologic and somatometric measurements were determined in children of pre-school age. There was a positive and statistically significant correlation between lung vital capacity and body height, mass, and chest circumference. The correlation between lung vital capacity and body mass index was not statistically significant. The main results do not differ from the results of similar studies in other countries. The obtained results will help to create a standard of morphological and somatometric parameters in pre-school aged children in Riga region.
\end{abstract}

Key words: pre-school children, body mass index, lung vital capacity.

\section{INTRODUCTION}

Nowadays the excess body weight in children and adolescents has become a worldwide problem. It is a risk factor for several non-communicable chronic diseases, such as insulin resistance, type II diabetes, high blood pressure, and metabolic syndrome (He et al., 2015). The latest data of the World Health Organization (WHO) show that in 2016 about 41 million of children under the age of 5 and over 340 million children and adolescents aged 5-19 were overweight or obese.

Children and adolescents with excess body fat are more likely to develop structural anatomical changes (postural deviations), increased heart workload (hypertrophy and cardiac arrhythmia), changes in pulmonary functions (airway obstruction and apnoea), endocrine disorders (insulin resistance, increased cortisol, and reduced growth hormone), and immunologic disorders (increased production of cytokines) (Eckel et al., 2016). In the Forum of International Respiratory Societies (2017) it was reminded that acute lower respiratory tract infections are among the top three causes of death and disability among both children and adults. Death from acute lower respiratory tract infections is the leading cause among children under age 5 . Lower respiratory tract infection kills more people than human immunodeficiency virus (HIV), TB and malaria combined (Wardlawet al., 2006).

One of the most commonly used methods for the assessment of respiratory system functions and the early diagnosis of the disease is spirometry. However, children aged 2 to 6 years represent one of the major challenges in lung functional assessment (Beydonet al., 2007). Spirometry is used to assess the normal respiratory function development as the child grows. For instance, in pre-school children who were 
born pre-term and whose anamnesis shows bronchopulmonary dysplasia (BPD), spirometry shows a marked response to bronchodilators, disrupted air flow, and lowered lung volume (Filbrun et al., 2011). Spirometry is used for the assessment of early diagnosis of respiratory function disorders and the effectivity of rehabilitation therapy in cases of neuromuscular, rheumatologic and haematologic diseases (Jordán et al., 2013).

The aim of this study was to evaluate the correlation between lung vital capacity and body mass index for preschool children aged 3-7 years in Rīga, Latvia.

\section{MATERIALS AND METHODS}

A total of 995 (527 girls and 468 boys) children from 22 different Rīga pre-school educational institutions (PSEI) were included in the study. Children age varied from 3 to 7 years (see Table 1).

Table 1. Distribution of children included in the study by age and gender

\begin{tabular}{lcc}
\hline Age (years) & No. of girls & No. of boys \\
\hline 3 & 16 & 20 \\
4 & 116 & 95 \\
5 & 154 & 127 \\
6 & 136 & 136 \\
7 & 105 & 90 \\
Total & 527 & 468
\end{tabular}

The pre-school educational institutions were randomly selected in the Rìga Region. The head of each pre-school educational institution was informed about the main points of the research. The parents received informative consent forms and agreed/disagreed to include their child in the study. If the parents agreed to the consent they filled a questionnaire about the development of their child. Participation in the study was voluntary for parents and children. Data from questionnaires, and inspection and measurements of the children were collected from March 2010 till December 2013. The measurements were obtained from 9 a.m. till 12 a.m. in the medical office of a pre-school educational institution or in the appropriate premises for the procedure. The measurements were performed by specially trained paramedical staff of Rīga Stradiňš University, Institute of Anatomy and Anthropology, Anthropology Department. The questionnaires and the study protocol were affirmed by the RSU Ethics Committee on 2010 firstly and on 2018 because of a change of the research head author.

For the study of children's morphological status, different somatometric measurements were performed: body height in a standing position $(\mathrm{cm})$, body mass $(\mathrm{kg})$, and chest circumference at the end of calm exhalation $(\mathrm{cm})$.

The body mass index (BMI) was calculated by the formula:

BMI $\left(\mathrm{kg} / \mathrm{m}^{2}\right)=\operatorname{mass}(\mathrm{kg}) /$ height $\left.(\mathrm{m})\right)^{2}$
According to WHO Child Growth Standards (Anonymous, 2006), the children included in the study were divided into three groups by their BMI ratio to the age and gender in percentiles (pc.): BMI-1 - children whose BMI is below 85 pc. in relation to age and gender, BMI-2 - children whose BMI is within 85-94 pc. in relation to age and gender (overweight), BMI-3 - children whose BMI is $\geq 95$. pc. in relation to age and gender (obesity).

All anthropometric measurements were performed according to the methodological recommendations of R. Martins (1914; 1928), K. Sallers (1957-1966) and J. Prīmanis (1937) (Prīmanis, 1937) using the instruments of the Swiss company Siber-Hagen\&Co.

Body mass was measured by electronic weights. The chest circumference was measured using a tape measure with millimetres.

The lung vital capacity (forced vital capacity (FVC)) was obtained by a portable air spirometer (RIESTER, Germany). Examination with spirometer was performed under the presence of trained staff in the following way: the measurement was performed with a child, with no change in the body position, most commonly in a sitting position, with the nose clip applied. Firstly the child made a maximal deep inhalation and then maximally fast exhalation into the spirometer. The highest result of the first three technically performed attempts was used for the analysis. Spirometric measurements according to the requirements could not be done by ten children.

Statistical processing of the acquired data was done using the software SPSS 22.0 and Microsoft Excel. Conducting data analysis, the main descriptive statistical indices were calculated - mean and standard deviation. The Spearman correlation coefficient was used for the evaluation of the relationships between variables. A $p$ value equal or less than 0.05 was considered to be statistically significant.

\section{RESULTS}

In the group of girls at the age of 3 years, the mean body height $(\mathrm{M})$ was $100.2 \pm 4.3 \mathrm{~cm}$ (minimum $93.0 \mathrm{~cm}$, maximum $109.7 \mathrm{~cm}$ ) (see Table 2). The mean height of 4-yearold girls was $103.2 \pm 5.7 \mathrm{~cm}$ (min. $85.9 \mathrm{~cm}$, max. 128.2 $\mathrm{cm})$. For 5-year-old girls the mean body height was $110.7 \pm$ $4.9 \mathrm{~cm}$ (min. $96.6 \mathrm{~cm}$, max. $124.2 \mathrm{~cm}$ ). At age 6, the mean body height was $117.7 \pm 5.7 \mathrm{~cm}(\min .104 .0 \mathrm{~cm}$, max. 131.7 $\mathrm{cm})$. For 7-year-old girls the body height was $122.5 \pm 5.4$ $\mathrm{cm}$ (min. $104.4 \mathrm{~cm}$, max. $139.2 \mathrm{~cm}$ ) (Table 2).

For boys at the age of 3 years, the mean body height was $99.9 \pm 4.9 \mathrm{~cm}(\min .89 .0 \mathrm{~cm}$, max. $109.7 \mathrm{~cm})($ Table 2). At the age of 4 years, the mean body height was $105.1 \pm 4.7$ $\mathrm{cm}$ (min. $90.0 \mathrm{~cm}$, max. $120.4 \mathrm{~cm}$ ). In 5-year-old boys the mean body height was $111.8 \pm 5.4 \mathrm{~cm}(\min .99 .6 \mathrm{~cm}$. max. $131.0 \mathrm{~cm}$ ). At the age of 6 years, the mean body height was $118.7 \pm 4.9 \mathrm{~cm}(\min .103 .4 \mathrm{~cm}, \max .131 .3 \mathrm{~cm})$. The mean 
Table 2. Descriptive statistics of children's body height $(\mathrm{cm})$ and body mass $(\mathrm{kg})$ in relation to age and gender

\begin{tabular}{l|c|c|c|c}
\hline \multirow{2}{*}{ Gender } & $\begin{array}{c}\text { Age } \\
\text { (years) }\end{array}$ & $\mathrm{N}$ & $\mathrm{M} \pm \mathrm{SD}$ & $\mathrm{M} \pm \mathrm{SD}$ \\
\cline { 4 - 5 } Girl & 3 & 16 & $100.2 \pm 4.3$ & Weight $(\mathrm{kg})$ \\
\hline & 4 & 116 & $103.2 \pm 5.7$ & $16.7 \pm 1.6$ \\
& 5 & 154 & $110.7 \pm 4.9$ & $19.2 \pm 2.9$ \\
& 6 & 136 & $117.7 \pm 5.7$ & $22.1 \pm 3.9$ \\
& 7 & 105 & $122.5 \pm 5.4$ & $23.7 \pm 3.9$ \\
\hline \multirow{2}{*}{ Boy } & 3 & 20 & $99.9 \pm 4.9$ & $16.3 \pm 1.9$ \\
& 4 & 95 & $105.1 \pm 4.7$ & $17.7 \pm 2.3$ \\
& 5 & 127 & $111.8 \pm 5.4$ & $19.6 \pm 2.8$ \\
& 6 & 136 & $118.7 \pm 4.9$ & $21.9 \pm 3.5$ \\
& 7 & 90 & $124.4 \pm 4.7$ & $24.9 \pm 3.7$
\end{tabular}

Table 3. Mean children's body height rate ( $\mathrm{cm} / \mathrm{year})$ and body mass rate ( $\mathrm{kg} /$ year) in relation to the age and gender

\begin{tabular}{|c|c|c|c|c|c|}
\hline \multirow[t]{2}{*}{ Gender } & & \multicolumn{4}{|c|}{ Age (years) } \\
\hline & & 3 till 4 & 4 till 5 & 5 till 6 & 6 till 7 \\
\hline Girls & Height rate (cm/year) & 3.0 & 7.5 & 7.0 & 4.8 \\
\hline Boys & & 5.2 & 6.7 & 6.9 & 5.7 \\
\hline Girls & Body mass rate (cm/year) & 0.1 & 2.4 & 2.9 & 1.6 \\
\hline Boys & & 1.4 & 1.9 & 2.3 & 3.0 \\
\hline
\end{tabular}

body height in the group of 7-year old boys was $124.4 \pm 4.7$ $\mathrm{cm}$ (min. $113.6 \mathrm{~cm}$, max. $135.8 \mathrm{~cm}$ ).

The growth rate in body height of pre-school age children in relation to age and gender is shown in Table 3.

In girls at the age of 3 years, the mean body mass was $16.7 \pm 1.6 \mathrm{~kg}$, the (min. $14.4 \mathrm{~kg}$, max. $20.1 \mathrm{~kg}$ ) (Table 2). The mean body mass in the group of 7-year-old girls was $23.7 \pm 3.5 \mathrm{~kg}$ (min. $14.5 \mathrm{~kg}$, max. $34.1 \mathrm{~kg}$ ). The increase of mean body mass in girls between the ages from 3 to 7 years was $7.0 \mathrm{~kg}$.

In boys at the age of 3 years, the mean body mass was 16.3 $\pm 1.9 \mathrm{~kg}$ (min. $12.1 \mathrm{~kg}$, max. $20.7 \mathrm{~kg}$ ) (Table 2). The mean body mass in the group of 7-year-old boys was $24.9 \pm 3.7$
Table 4. Descriptive statistics of the children's body mass index $\left(\mathrm{kg} / \mathrm{m}^{2}\right)$ in relation to age and gender

\begin{tabular}{l|c|c|c}
\hline Gender & Age (years) & $\mathrm{N}$ & $\mathrm{M} \pm \mathrm{SD}$ \\
\hline \multirow{4}{*}{ Girl } & 3 & 16 & $16.6 \pm 0.8$ \\
& 4 & 116 & $15.8 \pm 1.2$ \\
& 5 & 154 & $15.6 \pm 1.7$ \\
& 6 & 136 & $15.8 \pm 22.0$ \\
& 7 & 105 & $15.7 \pm 1.6$ \\
\hline \multirow{2}{*}{ Boy } & 3 & 20 & $16.3 \pm 0.9$ \\
& 4 & 95 & $15.9 \pm 1.2$ \\
& 5 & 127 & $15.6 \pm 1.4$ \\
& 6 & 136 & $15.5 \pm 1.6$ \\
& 7 & 90 & $16.1 \pm 1.6$
\end{tabular}

$\mathrm{kg}$ (min. $19.6 \mathrm{~kg}$, max. $40.0 \mathrm{~kg}$ ). The increase of mean body mass in boys between 3 to 7 years was $8.6 \mathrm{~kg}$.

The growth rate in body mass of pre-school age children in relation to age and gender is shown in Table 3.

Descriptive statistics of the relationship between children's BMI and age and gender are provided in Table 4. The number and proportion of children in body mass index classes, in relation to age and gender, are described in Table 5 .

Forced vital capacity was determined in 985 children, while in $10(1 \%)$ children the FVC could not be determined. FVC results, depending on age and gender, are summarised in Table 6.

For both boys and girls, FVC was correlated with growth (for girls $(\mathrm{n}=521): \mathrm{r}=0.70 ; p<0.001$; for boys $(\mathrm{n}=464)$ : $\mathrm{r}=0.68 ; p<0.001)$. The mean FVC was higher for boys than for girls.

The correlation between FVC and body height indicates that FVC increases with body height (Fig. 1). The correlation between FVC and body mass was also significant and positive (Fig. 2). There was positive correlation between FVC and chest circumference in both genders (Fig. 3). The cor-

Table 5. Absolute number $(\mathrm{N})$ and proportion $(\%)$ of pre-school age children in BMI classes (in line with BMI standards) in relation to age and gender

\begin{tabular}{|c|c|c|c|c|c|c|c|c|c|c|c|c|}
\hline & \multicolumn{10}{|c|}{ Age (years) } & \multirow{2}{*}{\multicolumn{2}{|c|}{ Total }} \\
\hline & \multicolumn{2}{|c|}{3} & \multicolumn{2}{|c|}{4} & \multicolumn{2}{|c|}{5} & \multicolumn{2}{|c|}{6} & \multicolumn{2}{|c|}{7} & & \\
\hline & $\mathrm{n}$ & $\%$ & $\mathrm{n}$ & $\%$ & $\mathrm{n}$ & $\%$ & $\mathrm{n}$ & $\%$ & $\mathrm{n}$ & $\%$ & $\mathrm{n}$ & $\%$ \\
\hline \multicolumn{13}{|c|}{ Girls } \\
\hline BMI-1 & 10 & 62.5 & 92 & 79.3 & 129 & 83.8 & 112 & 82.4 & 96 & 91.4 & 439 & 83.3 \\
\hline BMI-2 & 6 & 37.5 & 21 & 18.1 & 18 & 11.7 & 14 & 10.2 & 7 & 6.7 & 66 & 12.5 \\
\hline BMI-3 & 0 & 0.0 & 3 & 2.6 & 7 & 4.5 & 10 & 7.4 & 2 & 1.9 & 22 & 4.2 \\
\hline Total & 16 & 100,0 & 116 & 100.0 & 154 & 100.0 & 136 & 100.0 & 105 & 100.0 & 527 & 100.0 \\
\hline \multicolumn{13}{|c|}{ Boys } \\
\hline BMI-1 & 15 & 75.0 & 77 & 81.1 & 108 & 85.0 & 115 & 84.6 & 77 & 85.6 & 392 & 83.8 \\
\hline BMI-2 & 5 & 25.0 & 12 & 12.6 & 15 & 11.8 & 13 & 9.6 & 7 & 7.8 & 52 & 11.1 \\
\hline BMI-3 & 0 & 0.0 & 6 & 6.3 & 4 & 3.1 & 8 & 5.9 & 6 & 6.7 & 24 & 5.1 \\
\hline
\end{tabular}


Table 6. FVC (L) absolute values in relation to age and gender

\begin{tabular}{l|cccc}
\hline Gender & Age (years) & $\mathrm{N}$ & $\mathrm{M} \pm \mathrm{SD}$ \\
\hline \multirow{2}{*}{ Girl } & 3 & 14 & $0.28 \pm 0.06$ \\
& 4 & 113 & $0.51 \pm 0.23$ \\
& 5 & 154 & $0.73 \pm 0.24$ \\
& 6 & 134 & $1.00 \pm 0.28$ \\
& 7 & 105 & $1.14 \pm 0.26$ \\
\hline \multirow{2}{*}{ Boy } & 3 & 17 & $0.35 \pm 0.14$ \\
& 4 & 94 & $0.59 \pm 0.25$ \\
& 5 & 127 & $0.83 \pm 0.26$ \\
& 6 & 136 & $1.03 \pm 0.24$ \\
& 7 & 90 & $1.28 \pm 0.33$
\end{tabular}

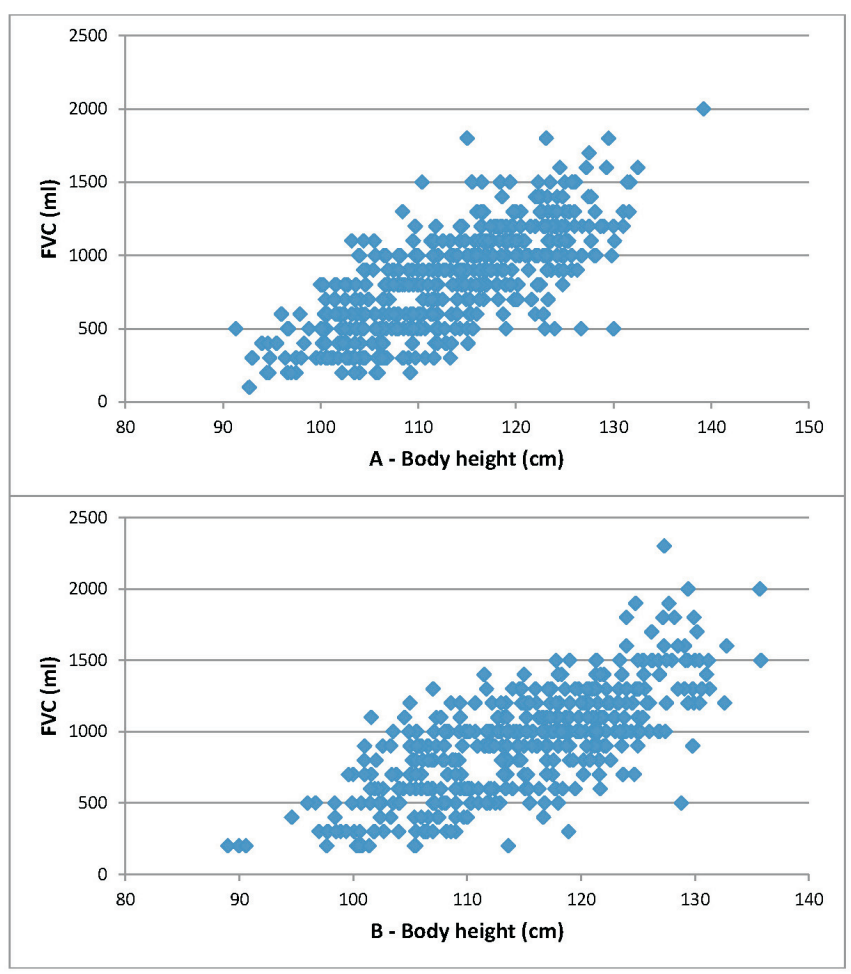

Fig. 1. FVC absolute values depending on body height of girls ( $\mathrm{r}=0.73 ; p$ $0.001 ; \mathrm{n}=521)(\mathbf{A})$ and boys $(\mathrm{r}=0,72 ; p 0,001 ; \mathrm{n}=464)(\mathbf{B})$.

relation between FVC and BMI (overweight and obesity) was not statistically significant for both genders (Fig. 4).

\section{DISCUSSION}

The first seven years in a child's life are very essential and affect a person's whole future life. At this age, the child acquires the power of locomotion. The development of language and intellect, intensive ossification and growth, and change of teeth occur in these years, and the period of the first accelerated growth comes to an end (Segleniece, 1977; Lašiene et al., 2007).

In our work, we analysed some anthropometric parameters of 995 pre-school age children (body mass, height, chest circumference), which were acquired by conducting a vast number of measurements during a period of three years.
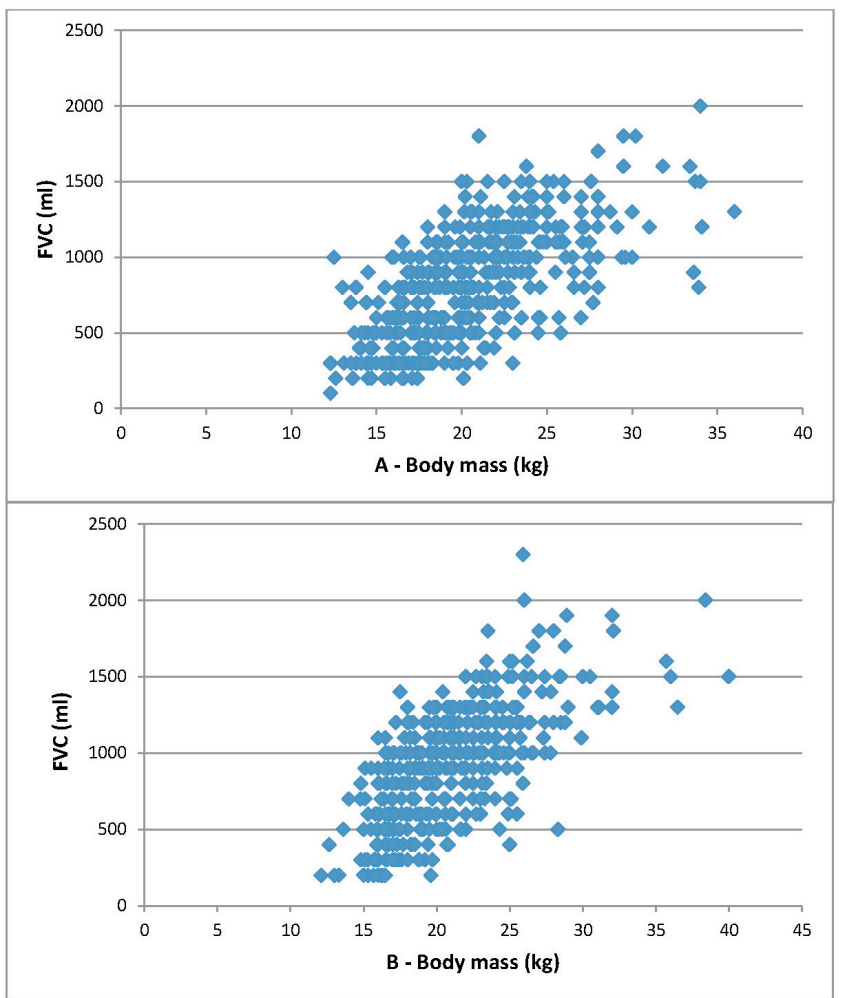

Fig. 2. FVC absolute values depending on body mass of girls $(\mathrm{r}=0.65 ; p<$ $0.001 ; \mathrm{n}=521)(\mathbf{A})$ and boys $(\mathrm{r}=0.67 ; p<0.001 ; \mathrm{n}=464)(\mathbf{B})$.
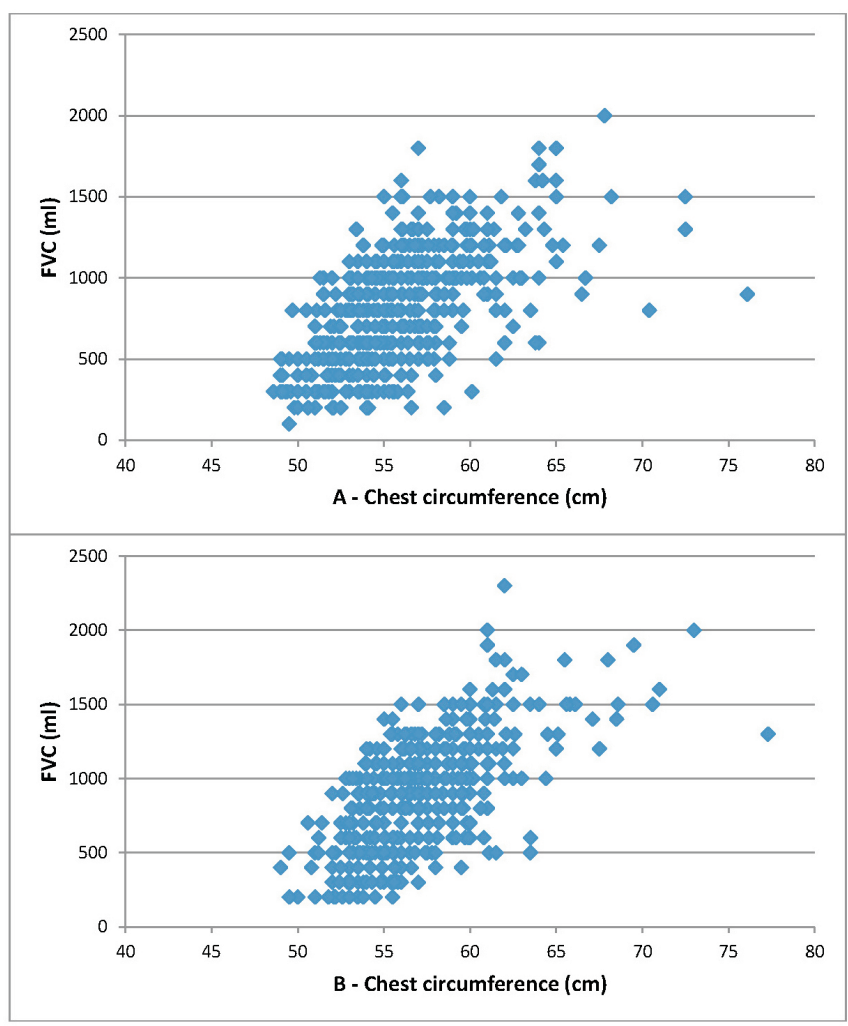

Fig. 3. FVC absolute values depending on chest circumference of girls $(\mathrm{r}=$ $0.60 ; p<0.001 ; \mathrm{n}=521)(\mathbf{A})$ and boys $(\mathrm{r}=0.63 ; p<0.001 ; \mathrm{n}=464)(\mathbf{B})$.

This was the first time in Latvia when respiratory vital capacity was assessed to determine the status of the respiratory system in such a high number of pre-school age 

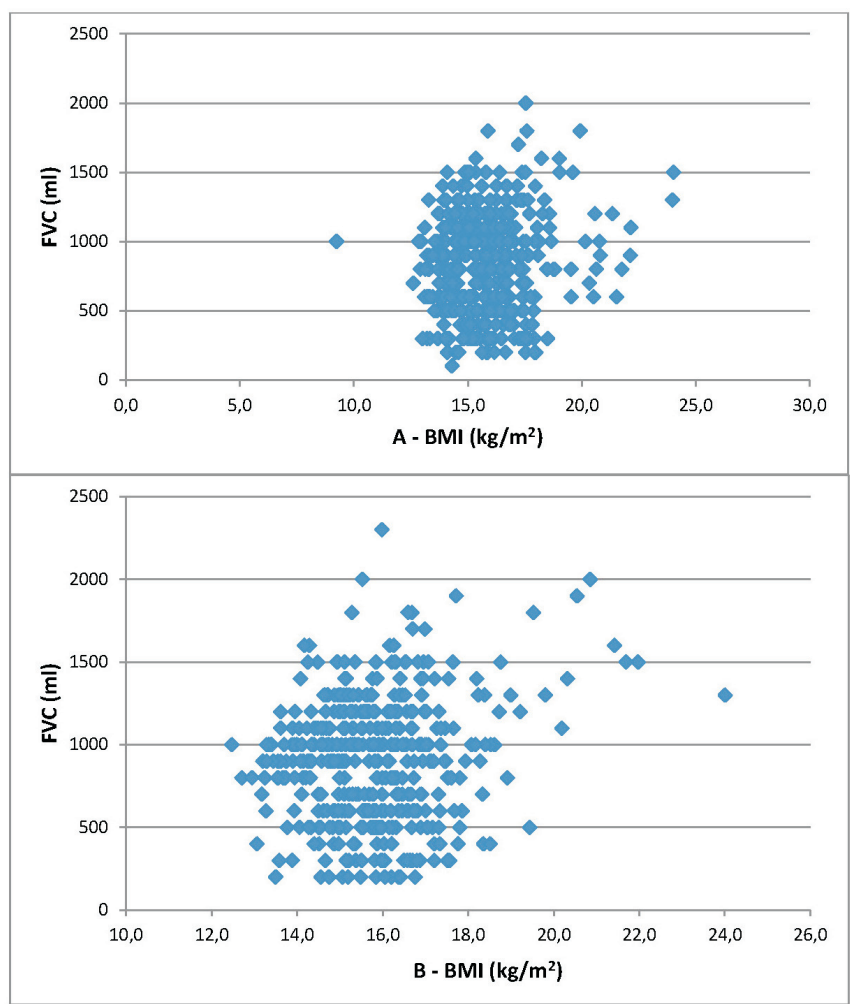

Fig. 4. FVC absolute values depending on BMI of girls ( $\mathrm{r}=0.07 ; p<0.11$; $\mathrm{n}=521)(\mathbf{A})$ and boys $(\mathrm{r}=0.07 ; p<0.11 ; \mathrm{n}=464)(\mathbf{B})$.

children. In the current study, we paid attention to the influence of the pre-school age children's main physical development parameters on lung functions estimated by forced vital capacity (FVC) parameters.

The body height parameters showed that the most intense growth rate for pre-school age children was from 4 to 6 years (girls on average grow, respectively, at a rate of 7.5 $\mathrm{cm}$ and $7.0 \mathrm{~cm}$ per year, boys $-6.7 \mathrm{~cm}$ and $6.9 \mathrm{~cm}$. Later, the average growth rate becomes slower for both genders; at the age from 6 to 7 years, average height growth is $4.8 \mathrm{~cm}$ and $5.7 \mathrm{~cm}$ for girls and boys, respectively (Table 3).

In the group of girls, the biggest increase in body mass was at the age from 4 to 6 years (on average by $2.4 \mathrm{~kg}$ and 2.9 $\mathrm{kg}$ per year, respectively). For the boys the most pronounced increase in body mass was $3.0 \mathrm{~kg}$ yearly, observed at the age from 6 to 7 years.

By using BMI we determined the incidence of overweight and obesity among the population of pre-school age children. The proportions of overweight and obese girls were $12.5 \%$ and $4.2 \%$, respectively, and in the group of boys $11.1 \%$ and $5.1 \%$ respectively.

The tendency for increase of chest circumference in preschool age was rather even and similar for both genders (on average by $2.0 \mathrm{~cm}$ per year).

The aim of our study was to measure absolute values of FVC and determine changes in spirometric data and lung vital capacity in relation to physical development parameters of children.
We used a portable air spirometer for FVC assessment, which is easy to use in the medical office of a primary care doctor when there is a need for the assessment of respiratory functions, both for patients at risk and for patients with already existing respiratory system disease. The data obtained by such a spirometer can be used either in clinical practice or for research purposes (Zanconato et al., 2005; Kirkby et al., 2008).

All of the included parameters (body mass, height and chest circumference) had a positive, statistically significant effect on FVC parameters. In our study, height had the greatest positive effect on FVC, which corresponds to literature data on increasing FVC in the pre-school age population while a child is growing (Quantjer et al., 2010; Luis et al., 2012). In order to precisely evaluate increase of FVC in relation to growth in height, height should be measured in a seated position (Stanojevic et al., 2008), because the growth of legs is faster than that of lungs. This explains why the lung functional parameters and lung volumes were similar for different age children.

Significant changes also take place in the thoracic configuration; initially it increases longitudinally, parts of costal cartilage and the breastbone drop lower than the respective thoracic vertebrae, and then the diaphragm domes drop till the lower level of the fifth rib (Grivas et al., 1991). The chest becomes elongated since its circumference increases proportionally more slowly than the body height.

For the assessment of the effect of body structure on FVC and other spirometric parameters, the correlation of BMI with lung functional parameters was taken into account. BMI was used to assess the incidence of overweight and obese children in the population, in relation to respiratory function. A series of studies on adults and children reported that presence of overweight and/or obesity was a risk factor for the development of bronchial asthma (Gugten et al., 2012).

In our study, an increased BMI did not have statistically significant positive or negative correlation with FVC parameters, but this does not exclude the fact that lung functions are not affected by overweight or obesity. In our study, we assessed only BMI to estimates body structure and did not consider the proportions of active body mass $(\mathrm{ABM})$ and passive body mass (PBM), which would have involved measurement of the thickness of fat folds in certain body parts. Increased BMI does not always indicate excessive fat amounts in the body (Sheikh et al., 2014). Our study results were similar to a study carried out in Germany in 2009 on six-year old children, which also reported effect of BMI on FVC (Kalhoff et al., 2009).

On the other hand, a series of studies found a negative effect of increased BMI on respiratory system functions, causing a decrease in FVC and other spirometric parameters (Poulain et al., 2006; Ülger et al., 2006). These crosssectional and prospective studies cannot fully describe the importance of BMI in the development of bronchial asthma 
and other respiratory diseases, because these diseases typically develop later than the study period. It is confirmed also by the studies that reported that a fast increase of BMI was a strong risk factor in the development of bronchial asthma in a later period (Bua et al., 2005; Sidoroff et al., 2011). Therefore, longitudinal studies are required to determine the influence of the body structure on the respiratory system functions more precisely. The vast number of analysed children in our study allows us to assess the condition of the pre-school age children population, which was previously assessed to such extent in the 1960s. We estimated children's body height, mass and chest circumference of this age group, thus allowing determination of growth rate.

The estimated BMI allows us to analyse the overweight and obesity tendencies among children, although to make a valid conclusion one should include also subcutaneous fat fold measurement results in further studies. The estimated lung vital capacity gives estimates respiratory system development and the health level of our pre-school age children. In further studies, BMI (Bua et al., 2005; Sidoroff et al., 2011), subcutaneous fat fold measurements, and FVC should be analysed, together with anamnesis data about previous illness, used medicines, verified asthma diagnosis, and tobacco smoke presence in the daily breathable air, which would allow to estimate the effect of various factors on children's respiratory system functions.

\section{CONCLUSIONS}

1. The mean body height in boys at the age from 4 to 7 years is higher than in girls in the respective age. The mean height increase for both genders between age 4 and 7 years is $19.3 \mathrm{~cm}$.

2. The mean body mass in pre-school girls and boys did not significantly differ. The increase of mean body mass in girls from 4 to 7 years was $6.9 \mathrm{~kg}$, and for boys $-7.2 \mathrm{~kg}$; the increase was rather even - on average by $2.4 \mathrm{~kg}$ per year.

3 . The chest circumference increases evenly between ages 4 and 7 years for both genders - on average by $5.5 \mathrm{~cm}$.

4. Overweight in a pre-school age was observed in $11.8 \%$ of children ( $12.5 \%$ girls, $11.1 \%$ boys), and obesity in $4.6 \%$ of children ( $4.2 \%$ girls, $5.1 \%$ boys).

5. The mean value of forced vital capacity in boys at the age from 4 to 7 years was higher than in girls in the respective age. The lung vital capacity increases with increase of age and the body parameters. Increase of body mass index was not significantly related with forced vital capacity.

\section{REFERENCES}

Anonymous (2006). Obesity and overweight. World Health Organization. Available from: https://www.who.int/en/news-room/fact-sheets/detail/obesity-and-overweight (accessed 16.02.2018).

Anonymous (2017). Forum of International Respiratory Societies. The Global Impact of Respiratory Disease. Second Edition. European Respiratory Society, Sheffield. $43 \mathrm{pp}$.
Beydon, N., Davis, S. D., Lombardi, E., Allen J. L., Arets, H. G. M., Aurora, P., Bisgaard, H., Davis, M., Ducharme, F. M., Eigen, H. et al. (2007). An Official American Thoracic Society/European Respiratory Society Statement: Pulmonary function testing in preschool children. Amer. J. Respir. Crit. Care Med., 175, 1304-1345.

Bua, J., M., Prescott, E., Schack-Nielsen, L., Petersen, L., Godtfredsen, N. S., Sørensen, T. I. , Osler (2005).Weight history from birth through childhood and youth in relation to adult lung function. Int. J. Obes., 29, 1055-1062.

de Onis, M. et al. (2006). WHO Child Growth Standards: length/ height-for-age, weight-for-age, weight-for-length, weight-for-height and body mass index-for-age: methods and development. WHO Press, Switzerland. $312 \mathrm{pp}$.

Eckel, N., Meidtner, K., Kalle-Uhlmann, T., Stefan, N., Schulze, M. B. (2016). Metabolically healthy obesity and cardiovascular events: A systematic review and meta-analysis. Eur. J. Prev. Cardiol., 23, 956-966.

Filbrun, A. G., Popova, A. P., Linn, M. J., McIntosh, N. A., Hershenson, M. B. (2017). Longitudinal measures of measures of lung function in infants with bronchopulmonary dysplasia. Pediatr. Pulmonol., 46 (4), 369-375.

Grivas, T. B., Burwell, R. G., Purdue, M., Webb, J. K., Moultonet, A. (1991). A segmental analysis, side and significance of lung growth and scoliosis. $J$. Anat., 178, 21-38.

Gugten, A. C., Koopman, M., Evelein, A. M. V., Verheij, T. J. M., Uiterwaal, C. S. P. M., van der Ent, C. K. (2012). Rapid early weight gain is associated with wheeze and reduced lung function in childhood. Eur. Respir. J., 39, 403-410.

He, F., Rodriguez-Colon, S., Fernandez-Mendoza, J., Vgontzas, A. N., Bixler, E. O., Berg, A., Liao D. (2015). Abdominal obesity and metabolic syndrome burder in adolescents - Penn State Children Cohort study. $J$. Clin. Densitom, 18, 30-36.

Jordán, Z., Tokodi, Z., Németh, A., Müller, J., Csóka, M., Mohl, A., Erdelyi, D. J., Kovacs, G. (2013). Examination of late pulmonary toxicity in children treated for malignancies. Orv. Hetil., 154 (9), 345-350.

Kalhoff, H., Breidenbach, R., Smith, H. J., Marek, W. (2009). Spirometry in preschool children: Time has come for new reference values. J. Physiol. Pharmacol., 60 (5), 67-70.

Kirkby, J., Welsh, L., Lum, S., Fawke, J., Rowell, V., Thomas, S., Marlow, N., Stocks, J. (2008). The EPICure study: Comparison of pediatric spirometry in community and laboratory settings. Pediatr. Pulmonol., 43 (12), 1233-1241.

Lašiene, D., Lašas, L., Dzīvīte, I. (2007) Bērnu augšanas un attīstības problēmas. Rekomendācijas [Problems of children growth and development. Recommendations]. Rīga. 4-18 lpp. (in Latvian).

Lozano, R., Naghavi, M., Foreman, K., Lim, S., Shibuya, K., Aboyans, V., Abraham, J., Adair, T., Aggarwal, R., Ahn, S. Y. et al. (2012). Global and regional mortality from 235 causes of death for 20 age groups in 1990 and 2010: A systematic analysis for the Global Burden of Disease Study 2010. Lancet, 380, 2095-2128.

Luís, H. S., da Cruz Santos, A., Sarmento de Oliveira, A., de Lima, M. (2012). Obesity and pulmonary function tests in children and adolescents: A systematic review. Rev. Paul Pediatr., 30 (3), 423-430.

Poulain, M., Doucet, M., Major, G. C., Drapeau, V., Séričs, F., Boulet, L. P., Tremblay, A., Maltais, F. (2006). The effect of obesity on chronic respiratory diseases: Pathophysiology and therapeutic strategies. Canad. Med. Assoc. J., , 174, 1293-1298.

Prīmanis, J. Ievads antropoloǵijas metodikā (Somatoskopija. Somatometrija) [Introduction to the Methodology of Anthropology (Somatoscopy. Somatometry)]. Valters un Rapa apgāds, Rīga. 96 lpp. (in Latvian).

Quanjer, P. H., Stanojevic, S., Stocks, J., Hall, G. L., Prasad, K. V., Cole, T. J., M. Rosenthal, R. Perez-Padilla, J.L. Hankinson, E. Falaschetti, et al (2010). Changes in the FEV1/FVC ratio during childhood and adolescence: An intercontinental study. Eur. Respir. J., 36, 1391-1399. 
Segleniece, K. (1977). Bērnu fiziskā attīstība [Physical Development of Children]. Zvaigzne, Rīga.79 lpp. (in Latvian).

Sheikh, S., Zemel, B. S., Stallings, V. A., Rubenstein, R. C., Kelly, A. (2014). Body composition and pulmonary function in cystic fibrosis. Front Pediatrics, 33 (2), 1-7.

Sidoroff, V., Hyvarinen, M., Matti, K. (2011). Lung function and overweight in school aged children after early childhood wheezing. Pediatric Pulmon., $46(5), 435-441$.

Stanojevic, S., Wade, A., Stocks, J., Hankinson, J., Coates, A. L., Pan, H., Rosenthal, M., Corey, M., Lebecque, P., Cole, T. J. (2008). Reference ranges for spirometry across all ages. A new approach. Amer. J. Respir. Crit. Care Med., 177, 253-260.

Ülger, Z., Demir, E., Tanaç, R., Gökşen, D., Gülen, F., Darcan, Ş. Can, D., Coker, M. (2006). The effect of childhood obesity on respiratory function tests and airway hyperresponsiveness. Turkisch J. Pediatrics, 48, 43-50.

Wardlaw, T. M., Johansson, E. W., Hodge, M., World Health Organization, UNICEF (2006). Pneumonia: The Forgotten Killer of Children. WHO Press. 40 pp.

Zanconato, S., Meneghelli, G., Braga, R., Zacchello, F., Baraldi, E. (2005). Office spirometry in primary care pediatrics: A pilot study. Pediatrics, 116 (6), 792-797.

\section{KORELĀCIJA STARP KERMENA MASAS INDEKSU UN PLAUŠU TILPUMU BĒRNIEM VECUMĀ NO 3 LĪDZ 7 GADIEM RĪGAS PIRMSSKOLAS IZGLİTİBAS IESTĀDĒS}

Katru gadu pasaulē pieaug cilvēku daudzums ar lieko svaru. Virssvars un aptaukošanās bērnībā var veicināt dažādas hroniskas saslimšanas pieaugušo vecumā. Bērniem ar lieko k̦ermeņa svaru novēro biežākas organisma morfoloğisko un somatometrisko parametru izmaiņas, tostarp arī plaušu funkciju izmainas. Viena no biežākajām metodēm plaušu funkcijas novērtēšanai ir spirometrija. Šĩ metode rada izaicinājumu plaušu funkciju novērtēšanā pirmsskolas vecuma bērniem. Šī pētījuma mērkis ir novērtēt korelāciju starp plaušu vitālo kapacitāti un ķermeņa masas indeksu pirmsskolas vecuma bērniem vecuma grupā no 3 līdz 7 gadiem Rīgas reǵionā. Pētījumā tika iekḷauti 995 bērni no pirmsskolas izglītības iestādēm. Pirms mērījumu veikšanas vecāki aizpildīja rakstisku ațauju iekḷaut bērnu pētījumā un anketu par bērna attīstību. Pētījumā tika veikti dažādi somatometriski mērījumi, iekḷaujot arī ḳermeņa masu, garumu, krūšukurvja apkārtmēru, plaušu vitālo kapacitāti. Šāda veida pētījums par dažādiem morfofunkcionāliem parametriem pirmsskolas vecuma bērniem Latvijā ir veikts pirmo reizi. Tika novērota pozitīva, statistiski ticama korelācija starp plaušu vitālo kapacitāti un ķermeņa garumu, masu, krūšukurvja apkārtmēru. Korelācija starp plaušu vitālo kapacitāti un k̦ermeṇa masas indeksu nebija statistiski ticama. Iegūtie rezultāti neatškīrās no citu valstu pētījumu datiem. Pētījuma rezultātus plānots izmantot parametru standartu izveidei pirmsskolas vecuma grupā Rīgas reğionā. 